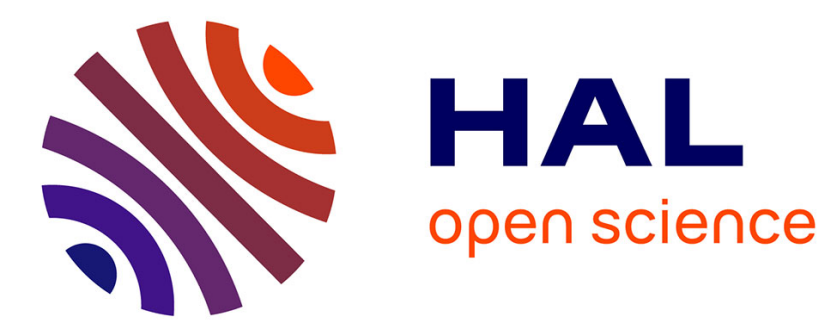

\title{
Interactions between hyperventilation and vertical ground reaction force in standing posture
}

\author{
Pascal David, Isabelle Mora, Michel Petitjean
}

\section{To cite this version:}

Pascal David, Isabelle Mora, Michel Petitjean. Interactions between hyperventilation and vertical ground reaction force in standing posture. Abstracts of the XVIIth Conference on Postural and Gait Research, May 2005, Marseille, France. pp.S145. hal-01064386

\section{HAL Id: hal-01064386 https://hal.science/hal-01064386}

Submitted on 16 Sep 2014

HAL is a multi-disciplinary open access archive for the deposit and dissemination of scientific research documents, whether they are published or not. The documents may come from teaching and research institutions in France or abroad, or from public or private research centers.
L'archive ouverte pluridisciplinaire HAL, est destinée au dépôt et à la diffusion de documents scientifiques de niveau recherche, publiés ou non, émanant des établissements d'enseignement et de recherche français ou étrangers, des laboratoires publics ou privés. 


\title{
Interactions between hyperventilation and vertical ground reaction
}

\section{force in standing posture}

\author{
Pascal DAVID $^{1}$, Isabelle MORA ${ }^{1}$ and Michel PETITJEAN ${ }^{2}$
}

${ }^{I}$ EA 3300 : APS et Conduites Motrices: Adaptations - Réadaptations, Université Picardie Jules Verne, Faculté des Sciences du Sport, 80025 Amiens cedex, France and ${ }^{2}$ Explorations Fonctionnelles du Système Nerveux, CHU, 80000 Amiens, France

P. David: EA 3300 : APS et Conduites Motrices, Université Picardie Jules Verne, Faculté des Sciences du Sport, Campus universitaire, 80025 Amiens cedex, France E-Mail: pascal.david@ca.u-picardie.fr

I. Mora: EA 3300 : APS et Conduites Motrices, Université Picardie Jules Verne, Faculté des Sciences du Sport, Campus universitaire, 80025 Amiens cedex, France Tel: +33-3-22827843

E-Mail: isabelle.mora@ca.u-picardie.fr

M. Petitjean: Explorations Fonctionnelles du Système Nerveux, Centre Hospitalier Régional Universitaire, Place Victor Pauchet, 80000 Amiens, France Tel: +33-3-22668185

E-Mail: petitjean.michel@.chu-amiens.fr

Topic: 27 - Techniques and methods of posture and gait analysis Preferred presentation form: poster 
Interactions between hyperventilation and vertical ground reaction force in standing posture

\section{$\underline{\text { Pascal DAVID }^{1}}$, Isabelle MORA ${ }^{1}$ and Michel PETITJEAN ${ }^{2}$}

${ }^{1}$ EA 3300: APS et Conduites Motrices: Adaptations - Réadaptations, Université Picardie Jules Verne, Faculté des Sciences du Sport, 80025 Amiens cedex, France and ${ }^{2}$ Explorations Fonctionnelles du Système Nerveux, CHU, 80000 Amiens, France

Purpose: This study examines the effects of a hyperventilation (HV) induced by a physical exercise on the fluctuations of the vertical ground reaction force $(\mathrm{Fz})$ in upright stance. Method: Twelve voluntary non-sedentary students were asked to maintain 30 seconds standing posture with open eyes on a force plate during quiet breathing (Pre-test) and after an incremental cycling exercise until exhaustion (Post-test). Over the 30 seconds of postural test, the mean amplitude of Fz fluctuations $(\Delta \mathrm{Fz})$ was calculated and a spectral analysis of $\mathrm{Fz}$ by mean of a fast Fourier transform gave the spectral energy (En) and the mean power frequency (MPF). Cardiac frequency (FC) and ventilation $(\dot{V} e)$ were measured with portable devices. Results and Discussion: Comparatively to the Pre-test values, HV led to a significant increase in FC and $\dot{V} e$, remaining at a high level 4 minutes following the end of exercise $(P<0.01)$, expressing the recovery of the oxygen debt. Linear regression analysis showed strong correlations $(P<0.0001)$ between $\Delta \mathrm{Fz}$ and $\mathrm{FC}(r=0.80)$ or $\dot{V} e(r=0.85)$. Whereas En also showed higher values in Post-tests, correlated to $\Delta \mathrm{Fz}(r=0.87), \mathrm{FC}(r=0.66)$ and $\dot{V} e(r$ $=0.74)$, the MPF values were lower and inversely correlated to FC $(r=-0.48)$ and $\dot{V} e(r=-$ 0.45). Thus, these results indicated that Fz depend on cardio-ventilatory changes during exercise. Conclusion: We conclude that hyperventilation during exercise up to maximal oxygen consumption lead to major postural disturbances showed by body oscillations in the frontal plane. Keywords: Posture; Hyperventilation; Vertical ground reaction force 